\title{
Patients with Special Needs: Dental Students' Educational Experiences, Attitudes, and Behavior
}

\begin{abstract}
Lauren Vainio; Meggan Krause; Marita R. Inglehart, Dr.phil.habil.
Abstract: Accreditation standards require U.S. dental schools to prepare their graduates for the diagnosis of treatment needs of patients with special health care needs (SHCN). The objective of this study was to explore dental students' perceptions of their education about these issues, their satisfaction with this education, and their professional attitudes and behavioral intentions concerning treating patients with SHCN in the future. Web-based survey data were collected from forty-nine dental student leaders in thirteen U.S. dental schools and paper-and-pencil survey data from 397 dental students at a Midwestern dental school. Most respondents agreed that it is important to be educated about providing care for patients with SHCN and that they will provide care for these patients in the future. However, their satisfaction with their education was not equally positive. Their perceived quality of their dental education was correlated with their confidence concerning treating SHCN patients; their confidence was in turn correlated with their intentions to include these patients in their patient families in their future professional lives. In conclusion, dental students are strongly motivated to learn about providing care for patients with SHCN. The better their dental education prepares them for this task, the more confident they will be when treating these patients and the more likely they will be to provide care for these patients.
\end{abstract}

\begin{abstract}
Ms. Vainio is a dental student at the University of Michigan; Ms. Krause is a dental student at the University of Michigan; and Dr. Inglehart is Associate Professor of Dentistry, Department of Periodontics and Oral Medicine, School of Dentistry, and Adjunct Associate Professor of Psychology, Department of Psychology, College of Literature, Science, and Arts, University of Michigan. Direct correspondence and requests for reprints to Dr. Marita Inglehart, Department of Periodontics and Oral Medicine, School of Dentistry, University of Michigan, 1011 North University Avenue, Ann Arbor, MI 48109-1078; 734-763-8073 phone; 734-763-5503 fax; mri@umich.edu.
\end{abstract}

Keywords: dental education, dental school curriculum, dental school programs, patients with special health care needs, special needs patients, disabilities, medically compromised patients, clinical education

Submitted for publication 4/27/10; accepted 7/1/10

$\mathrm{P}$ atients with special health care needs ( $\mathrm{SHCN}$ ) are a significant segment of the U.S. population. Research has found that more than 50 million U.S. residents or approximately one in five U.S. citizens have disabilities that challenge them in their activities of daily living. ${ }^{1}$ The Americans with Disabilities Act stated in 2005 that, of the 291.1 million U.S. citizens, 54.4 million or 18.7 percent had some level of disability and 35 million or 12 percent had a severe disability. These numbers of individuals with SHCN have been increasing over the past decades - which might be partly due to a longer life expectancy of persons with disabilities. ${ }^{2}$ In the oral health-related context, the Commission on Dental Accreditation (CODA) defines special needs patients as those "whose medical, physical, psychological, or social situations make it necessary to modify normal dental routines in order to provide dental treatment for that individual. These individuals include, but are not limited to, people with developmental disabilities, complex medical problems, and significant physical limitations" (p. 8). ${ }^{3}$ In 2000, the first U.S. surgeon general's report on oral health pointed out that patients with SHCN have poorer oral health than other patients and problems accessing oral health care services. ${ }^{4}$

The surgeon general's report also documented that patients who were medically compromised or who had disabilities were at a greater risk for oral diseases. ${ }^{4}$ Other studies have also documented that these patients encounter more challenges when seeking dental care. ${ }^{5}$ It is therefore crucial to educate future dental care providers in such a way that they will accept the professional responsibility to treat patients with SHCN.

In July 2004, CODA adopted Standard 2-26 that states: "Graduates must be competent in assessing the treatment needs of patients with special needs" (p. 15). ${ }^{3}$ This standard has been included in both the dental and the dental hygiene accreditation standards. ${ }^{3,6}$ The supporting statement of intent to the standard specified that "an appropriate patient 
pool should be available to provide a wide scope of patient experiences that include patients whose medical, physical, psychological, or social situations may make it necessary to modify normal dental routines in order to provide dental treatment for that individual" (p. 15). ${ }^{3}$

Research prior to this accreditation standard change had analyzed the educational efforts concerning preparing future dental care providers for their treatment of patients with SHCN. For example, in 2002, Waldman and Perlman found that dentists reported a lack of knowledge about providing care for patients with special needs and indicated that they did not have sufficient clinical experiences with these patients during their dental education. ${ }^{7}$ Schwenk et al. explored dental students' educational experiences concerning treating patients with SHCN before the new standard was introduced. ${ }^{8}$ They found that less than 50 percent of the participating dental school programs required their students to have any clinical experiences with patients with SHCN. In response to the new standards, Kleinert et al. developed a multimedia, virtual patient CD-ROM program to educate students with the help of case studies pertaining to the care of patients with SHCN. These authors concluded that this method of teaching was effective in addressing the requirements outlined in accreditation Standard 2-26. ${ }^{9}$

Two recent surveys explored how dental hygiene program directors and dental school administrators responded to these new standards concerning educating dental and dental hygiene students about patients with SHCN. Dehaitem et al. found that nearly all dental hygiene programs in the United States (98 percent) covered this material in lectures, but that only 42 percent required their dental hygiene students to gain clinical experiences with special needs patients. ${ }^{10}$ In a study conducted by Krause et al., ${ }^{11}$ dental school deans were surveyed about the ways that their schools educate students about patients with SHCN, which challenges they encounter, and which curricular changes they plan to implement. These authors found that 91 percent of the responding programs covered this topic in their students' clinical education. However, they also found that only 64 percent offered a separate course about the treatment of these patients.

Our study exploring dental students' perspectives on their education about patients with SHCN is a companion study to the research by Krause et al. ${ }^{11}$ While Krause et al. focused on the dental school administrators' perspectives, this study explored how students who entered dental school programs since the new standard was introduced in 2004 perceived their education concerning patients with SHCN and how satisfied they were with their education. Earlier research had found that dental education was related to practitioners' professional attitudes and behavior concerning providing care for underserved patients. In 2005, Dao et al. ${ }^{12}$ concluded that the better the dentists had been educated about providing care for patients with special needs, the better their attitudes were and the more likely they were to actually provide services for these patients. Additional research documented that educational experiences were clearly correlated with dentists' and even dental specialists' attitudes and behavior concerning underserved patients. ${ }^{13-15}$ Another study found that non-education-related factors, such as concerns about adequate compensation and about special arrangements needed when providing care for these patients, might also affect dentists' decisions to treat special needs patients. ${ }^{8}$

The majority of dentists in these earlier studies said they did not feel well prepared by their education. Casamassimo et al. found that only one in four dentists had received education about special care dentistry. ${ }^{16}$ These authors also found that the dentists who had not been exposed to these issues in lectures and clinical settings were less likely to treat patients with special health care needs than those who had. In addition, Wolff et al. reported in 2004 that 50 percent of dental students said they had not received any clinical training for the management of patients with mental retardation and that 75 percent said they had received little or no education or clinical training at all in the management of special needs patients. ${ }^{17}$

Given these findings, it seems worthwhile to revisit the question of how current dental students (those who began their education after the new standard was introduced) perceive their education about patients with SHCN and how these perceptions and their satisfaction with this education are related to their attitudes and professional behavior concerning patients with SHCN. Specifically, it will be interesting to explore how three sets of educational indicators relate to the respondents' attitudes and behaviors. These three sets of indicators are the students' educational experiences, their attitudes concerning education about this topic in general, and their satisfaction with their education on this topic. 


\section{Methods}

This study was approved by the Institutional Review Board for the Health Sciences at the University of Michigan (IRB HUM00002288).

A draft of the survey was designed by the investigators based on previously administered surveys. ${ }^{10,12-15}$ Questions concerning clinical services for the care of special needs patients were added. This first draft of the survey was piloted with the students, staff, and faculty members of the Multicultural Affairs Committee at the University of Michigan School of Dentistry. Their feedback was used to revise the survey and develop the final version. This final version was uploaded onto UM Lessons, an online system operated by the Information Technology Division at the University of Michigan for collecting web-based survey data.

Between July and August 2008, an e-mail was sent to fifty-four deans of student affairs at dental schools in the United States, asking them to forward the link to a web-based survey to their school's student leaders. The e-mail addresses of these deans were obtained from various school and the American Dental Education Association (ADEA) websites. It is unclear how many deans actually forwarded this e-mail, but forty-nine student leaders from thirteen schools had completed the survey by the end of October, when the website was closed. In addition, paperand-pencil surveys were distributed to the predoctoral dental students at the University of Michigan School of Dentistry at the end of regularly scheduled classes. The students responded anonymously by returning the survey in a sealed envelope to the investigators. A total of 397 surveys were collected from these dental students (response rate: 90 percent).

An introduction to the survey explained the purpose of the study and the fact that the survey was anonymous. The survey consisted of three sets of questions. The first questions focused on the students' background (see Table 1 for an overview of these questions). Questions in part 2 were concerned with the students' perceptions of the quality of their education about treating patients with SHCN, their attitudes towards this type of education (see Table 2 for the wording of these questions), and their satisfaction with the various aspects of this education (see Table 3 for an overview of these questions). Part 3 contained questions concerning the respondents' attitudes/confidence concerning treating patients with SHCN and asked whether the students intended to include patients with SHCN in their future practice/

\section{Table 1. Overview of survey respondents' background characteristics}

\begin{tabular}{lcc} 
& $\begin{array}{c}\text { Web-Based Survey } \\
\mathrm{N}=49\end{array}$ & $\begin{array}{c}\text { Paper Survey } \\
\text { N=397 }\end{array}$ \\
\hline From how many dental schools? & 13 & 1 \\
Year of program: & & $26 \%$ \\
$\quad$ st year & $4 \%$ & $25 \%$ \\
2nd year & $14 \%$ & $29 \%$ \\
3rd year & $35 \%$ & $20 \%$ \\
4th year & $41 \%$ & $1 \%$ \\
No answer & $6 \%$ & \\
Are you male or female? & & $53 \%$ \\
Male & $59 \%$ & $47 \%$ \\
Female & $41 \%$ & 25.12 \\
How old are you? & & 21 to 42 years \\
Average age & 25.77 & \\
Age range & $22 \%$ years & \\
Ethnicity/race & & $7 \%$ \\
African American & $2 \%$ & $17 \%$ \\
Asian American & $10 \%$ & $59 \%$ \\
European American & $74 \%$ & $15 \%$ \\
Latino/Hispanic & $2 \%$ & \\
Other & $12 \%$ & \\
Note: Percentages may not total $100 \%$ because of rounding. & \\
\hline
\end{tabular}


professional life (see Table 4 for the wording of these questions).

UM Lessons collects online survey data in the form of an Excel file. This file was imported into SPSS (Version 17.0) ${ }^{18}$ Descriptive statistics such as frequency distributions, means, and ranges were computed to describe the findings. Multivariate analyses of variance (MANOVA) were used to compare the average responses of the first- and second-year students versus the third- and fourth-

Table 2. Average responses concerning the quality of students' education about patients with special health care needs

\begin{tabular}{|c|c|c|c|c|c|c|}
\hline & $\begin{array}{l}\text { Type } \\
\text { of Survey }\end{array}$ & $\begin{array}{l}1 \text { st and } 2 \text { nd } \\
\text { Years }\end{array}$ & $\begin{array}{l}3 \text { rd } \\
\text { Year }\end{array}$ & $\begin{array}{l}\text { 4th } \\
\text { Year }\end{array}$ & $\begin{array}{c}\mathrm{P} \\
\text { (Year) }\end{array}$ & $\begin{array}{l}\text { Total } \\
\text { Mean }\end{array}$ \\
\hline \multicolumn{7}{|l|}{ Perceptions of Dental Education and Climate } \\
\hline $\begin{array}{l}\text { My classes prepared me well for treating patients with } \\
\text { special needs. }\end{array}$ & $\begin{array}{l}\text { Web-Based } \\
\text { Paper }\end{array}$ & $\begin{array}{l}3.86 \\
2.72\end{array}$ & $\begin{array}{l}2.63 \\
2.95\end{array}$ & $\begin{array}{l}3.05 \\
3.34\end{array}$ & $\begin{array}{l}.087 \\
<.001\end{array}$ & $\begin{array}{l}3.09 \\
2.91\end{array}$ \\
\hline $\begin{array}{l}\text { I believe that my dental school has an honest interest/ } \\
\text { concern for treating patients with special needs. }\end{array}$ & $\begin{array}{l}\text { Web-Based } \\
\text { Paper }\end{array}$ & $\begin{array}{l}4.43 \\
3.59\end{array}$ & $\begin{array}{l}3.81 \\
3.73\end{array}$ & $\begin{array}{l}4.37 \\
3.93\end{array}$ & $\begin{array}{l}.105 \\
.021\end{array}$ & $\begin{array}{l}4.19 \\
3.71\end{array}$ \\
\hline $\begin{array}{l}\text { The school clinics provide an environment that is } \\
\text { sensitive to treating patients with special needs. }\end{array}$ & $\begin{array}{l}\text { Web-Based } \\
\text { Paper }\end{array}$ & $\begin{array}{l}4.29 \\
3.24\end{array}$ & $\begin{array}{l}3.31 \\
3.44\end{array}$ & $\begin{array}{l}3.47 \\
3.44\end{array}$ & $\begin{array}{l}.142 \\
.134\end{array}$ & $\begin{array}{l}3.59 \\
3.34\end{array}$ \\
\hline MANOVA & $\begin{array}{l}\text { Web-Based } \\
\text { Paper }\end{array}$ & & \multicolumn{4}{|c|}{$\begin{array}{l}F(3 / 37)=1.553 ; p=.173 \\
F(3 / 372)=5.197 ; p<.001\end{array}$} \\
\hline \multicolumn{7}{|l|}{ Education-Related Attitudes } \\
\hline $\begin{array}{l}\text { The curriculum should include more education about } \\
\text { treating patients with special needs. }\end{array}$ & $\begin{array}{l}\text { Web-Based } \\
\text { Paper }\end{array}$ & $\begin{array}{l}3.29 \\
3.78\end{array}$ & $\begin{array}{l}4.00 \\
3.59\end{array}$ & $\begin{array}{l}3.39 \\
3.37\end{array}$ & $\begin{array}{l}.239 \\
.007\end{array}$ & $\begin{array}{l}3.57 \\
3.65\end{array}$ \\
\hline $\begin{array}{l}\text { It is very important to educate students about the } \\
\text { treatment of patients with special needs. }\end{array}$ & $\begin{array}{l}\text { Web-Based } \\
\text { Paper }\end{array}$ & $\begin{array}{l}4.71 \\
4.17\end{array}$ & $\begin{array}{l}4.69 \\
4.32\end{array}$ & $\begin{array}{l}4.44 \\
4.36\end{array}$ & $\begin{array}{l}.459 \\
.117\end{array}$ & $\begin{array}{l}4.61 \\
4.25\end{array}$ \\
\hline $\begin{array}{l}\text { I would like to have one more year as a resident before } \\
\text { I feel comfortable treating patients with special needs. }\end{array}$ & $\begin{array}{l}\text { Web-Based } \\
\text { Paper }\end{array}$ & $\begin{array}{l}3.57 \\
3.24\end{array}$ & $\begin{array}{l}3.06 \\
2.72\end{array}$ & $\begin{array}{l}2.61 \\
2.92\end{array}$ & $\begin{array}{l}.236 \\
.004\end{array}$ & $\begin{array}{l}2.93 \\
3.03\end{array}$ \\
\hline MANOVA & $\begin{array}{l}\text { Web-Based } \\
\text { Paper }\end{array}$ & & $\begin{array}{l}F(3 / 3 \\
F(3 / 36\end{array}$ & $\begin{array}{l}=1.224 \\
=6.52\end{array}$ & $\begin{array}{l}=.304 \\
<.001\end{array}$ & \\
\hline
\end{tabular}

Note: Answers to the web-based survey ranged from $1=$ Strongly Disagree to $4=$ Strongly Agree. Answers to the paper survey ranged from $1=$ Strongly Disagree to $5=$ Strongly Agree.

Table 3. Average responses concerning satisfaction with various aspects of education about treating patients with special health care needs

\begin{tabular}{|c|c|c|c|c|c|c|c|c|}
\hline Satisfaction with & $\begin{array}{l}\text { Type of } \\
\text { Survey }\end{array}$ & $\begin{array}{l}\text { 1st and 2nd } \\
\text { Years }\end{array}$ & $\begin{array}{l}3 \text { rd } \\
\text { Year }\end{array}$ & $\begin{array}{l}\text { 4th } \\
\text { Year }\end{array}$ & $\mathrm{p}$ & $\begin{array}{c}\mathrm{P} \\
(\text { Year })\end{array}$ & $\begin{array}{l}\text { Total } \\
\text { Mean }\end{array}$ & $\begin{array}{c}\mathrm{P} \\
\text { (school) }\end{array}$ \\
\hline classroom experience & $\begin{array}{l}\text { Web-Based } \\
\text { Paper }\end{array}$ & $\begin{array}{l}3.50 \\
3.11\end{array}$ & $\begin{array}{l}3.31 \\
3.42\end{array}$ & $\begin{array}{l}3.68 \\
3.78\end{array}$ & $\begin{array}{c}.463 \\
<.001\end{array}$ & .106 & $\begin{array}{l}3.50 \\
3.35\end{array}$ & .282 \\
\hline clinical experience & $\begin{array}{l}\text { Web-Based } \\
\text { Paper }\end{array}$ & $\begin{array}{l}2.50 \\
2.94\end{array}$ & $\begin{array}{l}3.13 \\
3.39\end{array}$ & $\begin{array}{l}3.22 \\
3.44\end{array}$ & $\begin{array}{c}.441 \\
<.001\end{array}$ & .157 & $\begin{array}{l}3.20 \\
3.18\end{array}$ & .918 \\
\hline extramural experience & $\begin{array}{l}\text { Web-Based } \\
\text { Paper }\end{array}$ & $\begin{array}{l}3.33 \\
2.93\end{array}$ & $\begin{array}{l}3.07 \\
3.34\end{array}$ & $\begin{array}{l}3.68 \\
3.38\end{array}$ & $\begin{array}{c}.042 \\
<.001\end{array}$ & .215 & $\begin{array}{l}3.50 \\
3.16\end{array}$ & .036 \\
\hline faculty expertise & $\begin{array}{l}\text { Web-Based } \\
\text { Paper }\end{array}$ & $\begin{array}{l}4.17 \\
3.32\end{array}$ & $\begin{array}{l}3.38 \\
3.64\end{array}$ & $\begin{array}{l}3.63 \\
3.69\end{array}$ & $\begin{array}{l}.218 \\
.005\end{array}$ & .830 & $\begin{array}{l}3.66 \\
3.50\end{array}$ & .329 \\
\hline patient pool & $\begin{array}{l}\text { Web-Based } \\
\text { Paper }\end{array}$ & $\begin{array}{l}3.25 \\
3.02\end{array}$ & $\begin{array}{l}3.53 \\
3.27\end{array}$ & $\begin{array}{l}3.16 \\
3.33\end{array}$ & $\begin{array}{l}.467 \\
.036\end{array}$ & .794 & $\begin{array}{l}3.37 \\
3.16\end{array}$ & .232 \\
\hline teaching resources & $\begin{array}{l}\text { Web-Based } \\
\text { Paper }\end{array}$ & $\begin{array}{l}4.00 \\
3.02\end{array}$ & $\begin{array}{l}3.25 \\
3.35\end{array}$ & $\begin{array}{l}3.47 \\
3.46\end{array}$ & $\begin{array}{l}.154 \\
.002\end{array}$ & .915 & $\begin{array}{l}3.50 \\
3.21\end{array}$ & .074 \\
\hline MANOVA & Web-Based/Paper & & & & & $\begin{array}{c}F(6 / 357)=1.431 \\
p=.146\end{array}$ & & $\begin{array}{c}F(6 / 357)=1.485 \\
p=.182\end{array}$ \\
\hline
\end{tabular}

Note: Answers ranged from $1=$ very dissatisfied to $5=$ very satisfied. 
year students. No inferential statistics were used to compare the responses to the educational questions of the University of Michigan students with those of the student leaders from other universities because the web-based survey used a four-point answer scale and the paper-and-pencil survey used a fivepoint answer scale for these questions. However, both surveys used five-point answer scales to assess respondents' satisfaction with the various aspects of their dental education about patients with SHCN. A multivariate analysis was therefore used to analyze if the responses of the students in the University of Michigan dental students differed from those in the other dental schools. Pearson correlation coefficients were computed to analyze the relationships between educational experiences and satisfaction with professional attitudes and behavior.

\section{Results}

As shown in Table 1, web-based survey data were collected from forty-nine predoctoral dental student leaders from thirteen U.S. dental school programs, and paper-and-pencil survey data were collected from 397 dental students at the University of Michigan School of Dentistry. Most of the students who answered the web-based survey were in the third or fourth year of their dental program, while the students who responded to the paper survey were equally distributed over the four years of the curriculum. Respondents in both groups were slightly more likely to be male and were on average about twenty-five to twenty-six years of age. In both samples, the majority of participants were from European American racial groups (74 percent in the web-based survey and 59 percent in the paper survey), followed by Asian American students (10 percent, 17 percent) and somewhat smaller percentages of African American ( 2 percent, 7 percent) and Latino ( 2 percent, 2 percent) students.

The first objective was to explore the students' educational responses concerning patients with SHCN. Table 2 provides an overview of the responses concerning the quality of their educational experiences and their attitudes related to this type of education. While the student leaders' web-based responses were given on a four-point scale with $1=$ strongly disagree, $2=$ disagree, $3=$ =agree, and $4=$ strongly agree, the University of Michigan students' responses on the paper-and-pencil survey were given on a five-point scale from $1=$ disagree strongly to $5=$ agree strongly. No comparisons between the respondents in the two groups were therefore made. However, the responses of first- and second-year students in each of these groups were compared with the responses of the third- and fourth-year students to gain a better understanding of the effects of the educational process over the course of the curriculum. Table 2 shows that the responses of the University of Michigan students to the three items concerning the perceptions of their education about treating patients with SHCN differed significantly between the combined first- and second-year versus third- and fourth-year students (MANOVA: $F(3 / 372)=5.197 ; p<.001$ ), while the responses of the dental student leaders did not differ significantly (MANOVA: $\mathrm{F}(3 / 37)=1.553 ; \mathrm{p}=.173$ ). The fourth-year University of Michigan students were most positive concerning how well their classes had prepared them and how much they believed that

Table 4. Professional attitudes and behavior concerning treating patients with special health care needs

\begin{tabular}{|c|c|c|c|c|c|c|}
\hline & $\begin{array}{l}\text { Type } \\
\text { of Survey }\end{array}$ & $\begin{array}{l}1 \text { st and } 2 \text { nd } \\
\text { Years }\end{array}$ & $\begin{array}{l}3 \text { rd } \\
\text { Year }\end{array}$ & $\begin{array}{l}\text { 4th } \\
\text { Year }\end{array}$ & $\begin{array}{c}P \\
\text { (Year) }\end{array}$ & $\begin{array}{l}\text { Total } \\
\text { Mean }\end{array}$ \\
\hline \multicolumn{7}{|l|}{ Professional attitudes } \\
\hline I feel comfortable treating patients with special needs. & $\begin{array}{l}\text { Web-Based } \\
\text { Paper }\end{array}$ & $\begin{array}{l}3.75 \\
3.15\end{array}$ & $\begin{array}{l}3.13 \\
3.21\end{array}$ & $\begin{array}{l}3.68 \\
3.51\end{array}$ & $\begin{array}{l}.292 \\
.029\end{array}$ & $\begin{array}{l}3.54 \\
3.24\end{array}$ \\
\hline $\begin{array}{l}\text { I feel comfortable having patients with special needs } \\
\text { as part of my patient population. }\end{array}$ & $\begin{array}{l}\text { Web-Based } \\
\text { Paper }\end{array}$ & $\begin{array}{l}4.13 \\
3.68\end{array}$ & $\begin{array}{l}3.81 \\
3.62\end{array}$ & $\begin{array}{l}4.05 \\
3.87\end{array}$ & .703 & $\begin{array}{l}4.00 \\
3.71\end{array}$ \\
\hline MANOVA & $\begin{array}{l}\text { Web-Based } \\
\text { Paper }\end{array}$ & \multicolumn{5}{|c|}{$\begin{array}{l}F(2 / 39)=635 ; p=.639 \\
F(2 / 376)=2.12 ; p=.077\end{array}$} \\
\hline \multicolumn{7}{|l|}{ Behavioral intentions } \\
\hline $\begin{array}{l}\text { I will include/treat special needs patients in my future } \\
\text { practice/professional life. }\end{array}$ & $\begin{array}{l}\text { Web-Based } \\
\text { Paper }\end{array}$ & $\begin{array}{l}4.25 \\
4.01\end{array}$ & $\begin{array}{l}4.31 \\
3.88\end{array}$ & $\begin{array}{l}4.37 \\
4.14\end{array}$ & $\begin{array}{l}.941 \\
.173\end{array}$ & $\begin{array}{l}4.28 \\
4.00\end{array}$ \\
\hline
\end{tabular}


their dental school had an honest interest/concern for treating patients with special needs compared to the other cohorts.

Concerning education-related attitudes, Table 2 shows the same pattern of findings, with the student leaders' responses not differing significantly between the various dental program cohorts, while the responses of the University of Michigan students in the first and second years differed from those of students in the third and fourth years. However, a closer look at the average means of these three groups shows that the fourth-year University of Michigan students actually responded more negatively than the students in the other cohorts to the statements that the curriculum should include more education about treating patients with $\mathrm{SHCN}$ and that they would like to complete a residency before they feel comfortable treating these patients.

In addition to analyzing the students' perceptions of the quality of their dental education and educational attitudes, six questions asked about the students' satisfaction with the various aspects of their education about treating patients with SHCN. These questions were concerned with the respondents' satisfaction with their classroom experiences, clinical experiences, extramural experiences, faculty expertise, the patient pool, and the teaching resources. Table 3 shows that the student leaders did not differ in their satisfaction ratings over the course of their predoctoral dental education. However, the average combined responses of first- and second-year students at the University of Michigan differed from the responses of the third- and fourth-year students at this school, with the fourth-year students being more satisfied than the students in the earlier cohorts. Overall, the students were only neutral to moderately satisfied with the various aspects of their education related to patients with $\mathrm{SHCN}$, with means ranging from 3.16 to 4.00 on a scale from 1 (very dissatisfied) to 5 (very satisfied) with 3 being a neutral response.

Concerning the students' professional attitudes and behavioral intentions, Table 4 shows that the professional attitudes were on average slightly positive, with means ranging from 3.24 to 4.00 . These attitudes were assessed with two questions asking the respondents how comfortable they were when treating patients with $\mathrm{SHCN}$ and how comfortable they would be with having special needs patients as part of their patient family. As expected, the fourthyear University of Michigan students said they were significantly more comfortable treating patients with special needs than were the students in the first and second years or the third year. However, the behavioral intentions of both groups of respondents did not change significantly over the course of their dental education. On average these behavioral intentions were quite positive.

The final objective of this study was to explore the relationships between the three sets of educational questions and the students' professional attitudes and behavioral intentions. Given the small number of student leaders who responded to the web-based survey and the heterogeneity of their programs, no correlations were computed for these students. The correlations reported in Table 5 were therefore based on the data of the University of Michigan students. This table shows that students' perception of the quality of their educational experiences, their educational attitudes, and their level of satisfaction with the various aspects of their education related to treating patients with SHCN correlated significantly with the comfort level the students had when treating these patients and having them as part of their patient families as well as their behavioral intentions. The comfort ratings were strongly correlated with the students' behavioral intentions to treat patients with $\mathrm{SHCN}$ in the future.

\section{Discussion}

In 2004, an amendment to the accreditation standards for predoctoral dental programs was introduced that requires these programs to educate their students about diagnosing the treatment needs of patients with SHCN by the time they graduate. The purpose of this study was to explore dental students' perceptions of their education about these issues, their attitudes towards their education on this topic in general, and their satisfaction with this education. In addition, the objective was to explore the relationships between these educational measures and the students' professional attitudes, specifically their comfort level and their behavioral intentions concerning treating patients with SHCN in the future. Before discussing the findings, it is important to reflect on the fact that while the response rate of students at the University of Michigan was quite satisfying, the sample size of student leaders from other U.S. dental schools was quite small. Only fortynine student leaders from thirteen of the fifty-four U.S. dental schools who had received a request for information responded to this survey. It is unclear if this low response rate was due to only thirteen of the 
fifty-five administrators who received the e-mailed request actually forwarding the recruitment e-mail to their student leaders or if more administrators forwarded the e-mail but did not succeed in motivating their student leaders to respond. In future studies, it would be helpful to ask the administrators to copy the research team on their e-mails and inform the research team about the number of student leaders that received their e-mail. Such a procedure would allow a determination of the response rate and would provide some background information about who might and might not have responded.
However, another reason for this low response rate could have been that students receive so many requests to participate in web-based surveys that they may be less likely to respond to them. ${ }^{1,16,17}$ In any case, the student leaders' low response rate limits the types of analyses that could be conducted. For example, given that only 4 percent of the forty-nine students were first-year dental students and only 14 percent were second-year dental students resulted in too few subjects to analyze the first- and second-year data separately. Because of this situation, the data were analyzed by combining the first- and second-

Table 5. Correlations among educational responses, attitudes, and behavioral intentions concerning patients with SHCN

I feel comfortable treating patients:

\begin{tabular}{|c|c|c|c|}
\hline & $\begin{array}{l}\text { with } \\
\text { SHCN }\end{array}$ & $\begin{array}{l}\text { with } \mathrm{SHCN} \text { as } \\
\text { part of my patient } \\
\text { population }\end{array}$ & $\begin{array}{l}\text { Behavioral } \\
\text { Intentions }\end{array}$ \\
\hline \multicolumn{4}{|l|}{ Perceptions of Dental Education/Climate } \\
\hline My classes prepared me well for treating patients with SHCN. & $.39 * * *$ & $.23^{* * *}$ & $.17^{* * *}$ \\
\hline $\begin{array}{l}\text { I believe that my dental school has an honest interest/concern for } \\
\text { treating patients with SHCN. }\end{array}$ & $.31^{* * *}$ & $.28^{* * *}$ & $.28^{* * *}$ \\
\hline $\begin{array}{l}\text { The school clinics provide an environment that is sensitive to } \\
\text { patients with SHCN. }\end{array}$ & $.31^{* * *}$ & $.23^{* * *}$ & $.24^{* * *}$ \\
\hline \multicolumn{4}{|l|}{ Education-Related Attitudes } \\
\hline $\begin{array}{l}\text { The curriculum should include more education about treating } \\
\text { patients with SHCN. }\end{array}$ & $-.12 *$ & .03 & $.19^{* * *}$ \\
\hline $\begin{array}{l}\text { It is very important to educate students about the treatment of } \\
\text { patients with SHCN. }\end{array}$ & $.13^{*}$ & $.26^{* * *}$ & $.30^{* * *}$ \\
\hline $\begin{array}{l}\text { I would like to have } 1>\text { year as a resident before I feel comfortable } \\
\text { treating patients with SHCN. }\end{array}$ & -.05 & $.32^{* * *}$ & $.22^{* * *}$ \\
\hline \multicolumn{4}{|l|}{ Satisfaction with: } \\
\hline Classroom experience & $.23^{* * *}$ & $.18^{* * *}$ & $.15^{* *}$ \\
\hline Clinical experience & $.36^{* * *}$ & $.21^{* * *}$ & .10 \\
\hline Extramural experience & $.27^{* * *}$ & $.13^{*}$ & .11 \\
\hline Faculty expertise & $.21^{* * *}$ & $.17^{* * *}$ & $.11^{*}$ \\
\hline Patient pool & $.31^{* * *}$ & $.19^{* * *}$ & $.11^{*}$ \\
\hline Teaching resources & $.34^{* * *}$ & $.23 * * *$ & $.12^{*}$ \\
\hline \multicolumn{4}{|l|}{ Professional Attitudes } \\
\hline I feel comfortable treating patients with $\mathrm{SHCN}$. & 1.00 & $.68^{* * *}$ & $.50^{* * *}$ \\
\hline $\begin{array}{l}\text { I feel comfortable having patients with } \mathrm{SHCN} \text { as part of my patient } \\
\text { population. }\end{array}$ & $.68^{* * *}$ & 1.00 & $.68^{* * *}$ \\
\hline \multicolumn{4}{|l|}{ Note: Correlations based on data of the University of Michigan students. } \\
\hline$* \mathrm{p} \leq .05, * * \mathrm{p}<.01, * * * \mathrm{p} \leq .001$ & & & \\
\hline
\end{tabular}


year students' responses and comparing them with the responses of the students in the third year and the fourth year. This study can therefore only be seen as a first step towards exploring these issues on a national basis.

Analyzing the student leader responses in general showed that these student leaders were not very positive about their educational experiences, with third- and fourth-year student leaders even disagreeing on average with the statement "My classes prepared me well for treating patients with special needs." These two cohorts also disagreed on average with the statement that their school clinics provide an environment that is sensitive to treating patients with special needs. Despite these negative responses, they were more positive about their school's concern for treating these patients. Concerning the student leaders' general attitudes towards their education about patients with SHCN, the data were neutral to positive in their responses to the statement that it is very important to educate students about the treatment of patients with special needs. However, they disagreed with the statement that they should have one more year as residents before they would feel comfortable treating patients with special needs. An interpretation of this last finding could consider that the students already felt well prepared and therefore did not want another year of education about this topic. Given the negative responses to the question about the quality of their education, the latter might be the case. A comparison of the responses of the four cohorts did not show any significant differences over the course of their dental school education.

Concerning the responses of the dental students from the University of Michigan, the data showed that the first- and second-year students felt less well prepared than the third- and especially the fourth-year students. These findings reflected that the students actually experience more education about these issues as they progress through the curriculum. This same pattern of increasingly more positive responses was also repeated in answers to questions about the climate in their dental school. In contrast, the education-related attitudes about the importance of educating students about the treatment of patients with special needs were quite positive over the course of the four-year dental education, and responses concerning the statement about including more education about these issues in the curriculum were positive as well. It would be worthwhile to explore whether the students interpreted this item as suggesting the inclusion of more classroom-based education and whether they would be more positive if they were asked about increasing their clinical education about these issues. Future research should carefully analyze how students' responses differ when evaluating classroom-based educational experiences versus clinic-based experiences or even extramural experiences such as experiences in nursing homes or independent living communities for persons with disabilities.

Table 3 provides an overview of the third set of educational responses, which were concerned with the students' satisfaction with six aspects of their education about this material. Overall, the responses ranged from neutral (2.50 to 3.49) to more positive ( 3.50 to 4.00 ) with the evaluations of the clinical experiences being most negatively rated. These findings are unfortunate in consideration of the results by Kinne and Stiefel, ${ }^{19}$ who found that the majority of dental students will treat patients with SHCN if they feel capable of treating these patients. Overall, the student leaders' responses did not differ from the responses of the students at the University of Michigan. Concerning differences in the satisfaction ratings over the course of the program, the data showed that the responses of the student leaders in the first and second years versus the third and fourth years did not differ, but that there was a systematic trend for the students at the University of Michigan to become more satisfied as they progressed through their curriculum. This finding is most likely related to the fact that the students receive mostly classroom-based education about patients with SHCN during their first two years and that the focus then shifts to more clinic-based education in the third and fourth years.

The students' responses concerning how comfortable they were when treating patients with SHCN and having them as part of their patient population were quite positive (see Table 4). These findings are consistent with the conclusions of Wolff et al., who found that the more experience dental students had with treating persons with intellectual disabilities, the more positive their attitudes concerning this population. ${ }^{17}$

Finally, the fact that the respondents in both groups were on average quite positive that they would include special needs patients in their future practice/professional life was quite encouraging. Table 5 provides more insight into which factors were related to these positive behavioral intentions. These data showed that the better the quality of the students' education about these issues and the better their education-related attitudes, the more positive 
were their behavioral intentions. The more comfortable the respondents were treating patients with SHCN, the more likely they were to intend to treat these patients in the future.

These findings should alert dental educators to the importance of educating future dentists well about providing care for patients with SHCN if they are interested in reducing the access to care problems for these patients. While classroom-based education can set the stage and prepare the students for their clinical activities, clinic-based education might be crucial in ensuring that dental students gain the confidence and level of comfort they need to be willing to treat these patients in their future practices. Unfortunately, CODA Standard 2-26 might not go far enough in motivating schools to engage in good clinic-based educational activities because it states that "Graduates must be competent in assessing the treatment needs of patients with special needs." Given these findings, one can argue that this standard should be extended beyond diagnosis to being able to provide basic care for these patients. If future providers do not acquire the clinical confidence needed to feel comfortable when treating these patients, they may be less likely to include these patients in their future patient families. Fenton described this situation well in an editorial concluding that dentists who do not have sufficient clinical experiences "will not feel confident inviting these individuals into their private practices." ${ }^{20}$

One could even argue that extramural experiences with patients with SHCN would be beneficial based on the research by Lyons, who found that students who had contact with individuals with disabilities beyond the caregiver/patient relationship reported significantly more positive attitudes toward these individuals than did those without such contact. ${ }^{21}$ This author concluded that students with more positive attitudes were more likely to interact with persons with disabilities in situations that place emphasis on valued attributes of the individual.

Our study had several limitations. First, the sample of dental school leaders was small and included results from only thirteen dental schools. It is possible that only administrators who felt their program did a good job in educating their students about patients with SHCN forwarded the recruitment e-mail. If this were the case, the overall responses would have been more negative if students from other programs had responded as well. Second, by focusing on student leaders from various schools, it is unclear how students in general perceive their education in this context. Third, by not analyzing data from student leaders in the same schools over time, it is impossible to explore if the trend that was found in the University of Michigan data that showed an improvement over time would also have been found in the other schools. It seems worthwhile therefore to explore these issues in future research. Fourth, comparing data from the student leaders who responded to a web-based survey with the responses of the University of Michigan students who answered on a paper survey is quite challenging, especially because of the scaling differences. Such comparisons were therefore not directly pursued in these analyses, and only very tentative preliminary comparisons were made. Fifth, while behavioral intentions are excellent predictors of future behavior, ${ }^{22,23}$ a study of actual behavior of, for example, alumni could have explored whether the practitioners' dental education experiences were actually correlated with their professional behavior. Finally, this study focused generally on patients with SHCN. Future research should analyze how these future providers would respond to pediatric versus adult patients with SHCN. Research has shown that general dentists who were not exposed to children with special needs during their training were less likely to treat these patients in their practice than those with such experience. ${ }^{16}$

\section{Conclusions}

Dental students at the University of Michigan as well as dental student leaders from other U.S. dental schools reported that their dental education about treating patients with SHCN was not exceptionally positive. However, they had a more positive attitude towards dental education about this topic as indicated by their responses to the statement "It is important to educate students about the treatment of patients with special needs." Responses concerning the dental students' satisfaction with various aspects of their education about this topic showed that the satisfaction with their classroom-based education was higher than their satisfaction with various aspects of their clinical education. Student leaders were tentatively comfortable with treating patients with SHCN and having them as part of their patient families in the future, and they were quite positive concerning treating patients with SHCN in the future. Students at the University of Michigan demonstrated an increased comfort level with treating these patients over the course of their program and were also quite positive about providing care for these patients in the future. 
Positive educational experiences and educational attitudes as well as satisfaction with the education about patients with SHCN correlated significantly with professional attitudes and behavioral intentions in this context. The more comfortable the students were, the more likely they were to indicate that they would treat these patients in the future.

\section{REFERENCES}

1. Waldman HB, Fenton SJ, Perlman SP, Cinotti DA. Preparing dental graduates to provide care to individuals with special needs. J Dent Educ 2005;69(2):249-54.

2. American Association on Intellectual and Developmental Disabilities. FAQ on intellectual disability. At: www.aamr. org/content_104.cfm. Accessed: February 1, 2010.

3. Commission on Dental Accreditation. Accreditation standards for dental education programs. Chicago: American Dental Association, 2007. At: www.ada.org/sections/ educationAndCareers/pdfs/current_predoc.pdf. Accessed: November 16, 2010.

4. Oral health in America: a report of the surgeon general. Rockville, MD: U.S. Department of Health and Human Services, National Institute of Dental and Craniofacial Research, National Institutes of Health, 2000.

5. Mueller CD, Schur CL, Paramore LC. Access to dental care in the United States. J Am Dent Assoc 1998; 129(4):429-37.

6. Commision on Dental Accreditation. Standard 2-16: clinical sciences. Accreditation standards for dental hygiene programs. Chicago: American Dental Association, January 1, 2010. At: www.ada.org/prof/ed/accred/standards/ dh.pdf. Accessed: February 1, 2010.

7. Waldman HB, Perlman SP. Preparing to meet the dental needs of individuals with disabilities. J Dent Educ 2002; 66(1):82-5.

8. Schwenk DM, Stoeckel DC, Rieken SE. Survey of special patient care programs at U.S. and Canadian dental schools. J Dent Educ 2007;71(9):1153-9.

9. Kleinert HL, Sanders C, Mink J, Nash D, Johnson J, Boyd S, Challman S. Improving student dentist competencies and perception of difficulty in delivering care to children with developmental disabilities using a virtual patient module. J Dent Educ 2007;71(2):279-86.
10. Dehaitem MJ, Ridley K, Kerschbaum WE, Inglehart MR. Dental hygiene education about patients with special needs: a survey of U.S. programs. J Dent Educ 2008; 72(9):1010-19.

11. Krause M, Vainio L, Zwetchkenbaum S, Inglehart MR. Dental education about patients with special needs: a survey of U.S. and Canadian dental schools. J Dent Educ 2010;74(11):1179-89.

12. Dao LP, Zwetchkenbaum S, Inglehart MR. General dentists and special needs patients: does dental education matter? J Dent Educ 2005;69(10):1107-15.

13. Brown BR, Inglehart MR. Orthodontists' and orthodontic residents' education in treating underserved patients: effects on professional attitudes and behavior. J Dent Educ 2009;73(5):550-62.

14. Rich JP III, Straffon L, Inglehart MR. General dentists and pediatric dental patients: the role of dental education. J Dent Educ 2006;70(12):1308-15.

15. Smith CS, Ester TV, Inglehart MR. Dental education and care for underserved patients: an analysis of students' intentions and alumni behavior. J Dent Educ 2006;70(4): 398-408.

16. Casamassimo PS, Seale NS, Ruehs K. General dentists' perceptions of educational and treatment issues affecting access to care for children with special health care needs. J Dent Educ 2004;68(1):23-8.

17. WolffAJ, Waldman HB, Milano M, Perlman SP. Dental students' experiences with and attitudes toward people with mental retardation. J Am Dent Assoc 2004;135(3):353-7.

18. SPSS Inc. SPSS 17.0 Student Version for Windows (SA). New York: Prentice Hall, 2009.

19. Kinne RD, Stiefel DJ. Assessment of student attitude and confidence in a program of dental education in care of the disabled. J Dent Educ 1979;43(5):271-5.

20. Fenton SJ. People with disabilities need more than lip service (editorial). Spec Care Dent 1999;19:198-9.

21. Lyons M. Enabling or disabling? Students' attitudes toward persons with disabilities. Am J Occup Ther 1991; 45(4):311-6.

22. Ajzen I, Fishbein M. Attitudinal and normative variables as predictors of specific behaviors. J Pers Soc Psychol 1973; 27:41-57.

23. Ajzen I, Fishbein M. The prediction of behavioral intentions in a choice situation. J Exp Soc Psychol 1969;5: 400-16. 